\title{
PENGATURAN PENGGABUNGAN USAHA (MERGER) BANK SEBAGAI UPAYA PENINGKATAN KESEHATAN BANK DI INDONESIA DALAM PEMBANGUNAN HUKUM EKONOMI NASIONAL
}

\author{
Agus Prihartono PS \\ Dosen Fakultas Hukum Universitas Sultan Ageng Tirtayasa \\ e-mail: agusnana79@ rocketmail.com
}

\begin{abstract}
Abstrak-Memburuknya kondisi perbankan nasional pada masa orde baru memasuki fase reformasi salah satu penyebabnya adalah lemahnya struktur permodalan bank. Modal adalah dana yang diinvestasikan oleh pemilik dalam rangka pendirian badan usaha yang dimaksudkan untuk membiayai kegiatan usaha bank di samping memenuhi peraturan yang ditetapkan. Penguatan struktur permodalan menjadi salah satu alasanbank-bank kecil melakukan merger dan akuisisi. Penggabungan usaha (merger) bank sendiri bukan merupakan hal yang baru, penggabungan bank yang pernah dilakukan, tidak hanya untuk bank-bank swasta nasional, tetapi juga pada bank-bank pemerintah. Merger (penggabungan usaha) bank tidak selalu menghasilkan bank yang sehat. Pelaksanaan merger bank guna mencapai suatu sinergi tidaklah mudah, banyak faktor-faktor yang harus diperhatikan (menghasilkan bank yang sehat), yaitu, mencari patner yang komplementer, sinergis dan mematuhi peraturan perundang-undangan.
\end{abstract}

Kata Kunci: Merger, Perbankan, Kesehatan Bank, Hukum Ekonomi Nasional.

Abstract-One of the reasons for the deteriorating condition of the national banking system in New Regime period transition to Reformation Period, is because the bank's capital structure is weak. Beside to fulfill the rules prescribed, Capital is the fund invested by the owner to establish an enterprise that is intended to support financial purposes of the bank business activities. The strengthening of the capital structure becomes one of the reasons small banks are doing mergers and acquisitions. Bank merger itself is not a new thing. As in the record, A bank merger is not only for national private banks, but also for the government banks. Banks merger do not always produce healthy banks. The implementation of them in order to achieve a synergy is not easy. Many factors must be considered (to produce a healthy bank), such as seeking partners who are complementary, synergistic and submissive with regulations.

Keywords: Mergers, Banking, Healty Bank, National Economic Law.

\section{A. PENDAHULUAN}

Bank sebagai salah satu agen pembangunan, berfungsi sangat penting dalam perekonomian negara. Sebagai contoh krisis keuangan yang melanda Asia tahun 1997-1998, dan diperburuk oleh krisis politik di tanah air sepanjang tahun hingga pertengahan 2001, telah menjerumuskan bangsa Indonesia ke dalam jurang keterpurukan dan ketidakpastian yang luar biasa. 
Pertumbuhan ekonomi Indonesia di tahun 1998 mencapai titik terendah sejak era Soeharto yakni minus $13 \%$. Banyak perusahaan konglomerasi baik yang bergerak di sektor riil maupun jasa perbankan yang gulung tikar atau harus masuk ke dalam pengawasan Badan Penyehatan Perbankan Nasional (BPPN) (I Nyoman Tjager, et. al, 2003:2).

Keterpurukan dunia perbankan mengakibatkan banyak bank yang mengalami kesulitan keuangan (financial) dan akhirnya tidak sedikit bank-bank yang dilikuidasi, dibekukan atau direkapitalisasi oleh pemerintah (Agus Sugiarto, Kompas, 5 Juni 2003). Keterpurukan dunia perbankan ini pada akhirnya mempengaruhi semua aspek kehidupan, baik aspek ekonomi, aspek sosial, maupun politik. Kepercayaan nasabah menjadi berkurang, nasabah banyak yang menarik uangnya dari bank dan memindahkannya ke luar negeri atau menyimpannya sebagai dolar di bank asing.

Ketidakmampuan sistem perbankan nasional menghadapi tekanan dari luar (external shocks) tersebut yang berakibat pada runtuhnya sistem perbankan pada saat itu membuktikan bahwa sistem perbankan Indonesia masih belum siap secara keseluruhan dalam menghadapi krisis besar yang terjadi secara tiba-tiba. Untuk itu kestabilan sistem perbankan maupun keuangan harus dipertahankan secara berkesinambungan dan dapat dicegah sedini mungkin.

Berbagai kebijakan dari mulai dibentuknya Arsitektur Perbankan Indonesia (API) sebagai blue print perbankan yang terdiri dari 6 (enam) pilar. Pilar I API yaitu penguatan struktur perbankan nasional sampai dengan adanya paket kebijakan Oktober 2006 tentang adanya kebijakan single presence policy menetapkan bahwa setiap bank perorangan maupun korporasi, hanya boleh menjadi pemegang saham pengendali pada satu bank. Tujuannya adalah untuk konsolidasi perbankan dan mendukung efektivitas pengawasan bank. Hal ini adalah untuk mewujudkan perbankan yang sehat dengan modal yang kuat. Modal merupakan salah satu faktor yang penting bagi bank dalam rangka 
pembangunan usaha dan menampung risiko kerugian. Salah satu kebijakan yang paling populer diambil untuk mewujudkan perbankan yang sehat dengan modal yang kuat saat itu adalah dilakukannya merger (penggabungan usaha bank).

Penguatan struktur permodalan menjadi salah satu alasan bank-bank kecil melakukan merger dan akuisisi. Selain karena adanya aturan pemenuhan modal inti minimum sebesar Rp. 100 miliar pada akhir 2010, penguatan struktur permodalan dibutuhkan bank umum demi mengantisipasi Association of South East Asian Nation (ASEAN) One Market atau pasar tunggal ASEAN pada 2015 dan terkait dengan ketentuan Basel III yang mengharuskan bank umum menaikkan modal minimum mereka hingga $10,5 \%$.

$$
\text { Merger sendiri bukan }
$$
merupakan hal yang baru, merger bank yang pernah dilakukan, tidak hanya untuk bank-bank swasta nasional, tetapi juga pada bank-bank pemerintah. Pada tahun 1999, terjadi merger pada 4 (empat) BUMN yaitu Bank Dagang Negara, Bank Ekspor
Impor Indonesia, Bank Bumi Daya, dan Bank Pembangunan Indonesia menjadi PT. Bank Mandiri. Sementara tahun 2002 terjadi merger 5 (lima) bank swasta nasional yaitu: Bank Bali, Bank Universal, Bank Artamendia, Bank Express, dan Bank Patriot, yang bergabung menjadi Bank Permata, pada tahun 2004 terjadi merger antara Bank CIC Internasional, Bank Danpac, dan Bank Pikko menjadi Bank Century, dan terakhir merger antara Bank Lippo dengan Bank Niaga. Namun demikian, pengaturan mengenai penggabungan badan usaha secara lengkap di Indonesia dalam bentuk undang-undang belum ada, khususnya penggabungan dalam bidang perbankan, walaupun Undang-undang Nomor 40 Tahun 2007 Tentang Perseroan Terbatas (selanjutnya disebut UUPT) sudah mengatur mengenai penggabungan badan usaha dalam Pasal 122-Pasal 137 UUPT.

Pelaksanaan merger bank guna mencapai suatu sinergi tidaklah mudah, banyak faktor-faktor yang harus diperhatikan (menghasilkan bank yang sehat), yaitu, mencari patner yang komplementer, sinergis 
dan mematuhi peraturan perundangundangan. Merger antara suatu bank dengan bank lain itu bukan hanya semata soal teknis saja, tapi juga menyangkut budaya kerja antar unit bank, sehingga proses merger harus dipelajari dan dilakukan secara hatihati (Burhanudin Abdullah, Tempo, 16 Februari, 2005). Karena itu, sebelum bergabung banyak hal yang harus dilakukan, termasuk kalkulasi keuntungan dan kerugian transaksi penggabungan antar bank. Bank yang belum mengetahui dengan jelas calon mitra mergernya, memerlukan waktu untuk pendekatan, khususnya pendekatan dalam aspek keterbukaan. Keterbukaan itu menyangkut baik kondisi keuangan (financial), kekayaan (assets), namun demikian, keterbukaan ini tidak boleh bertentangan dengan aspek kerahasiaan bank.

\section{B. HASIL DAN PEMBAHASAN}

\section{Penggabungan Usaha (Merger) Pada Umumnya}

Kepemilikan usaha bank dapat beralih kepada pihak lain melalui penyatuan usaha (combination atau busines amalgamation) bank dalam memperkuat dirinya guna mewujudkan sistem perbankan yang sehat, efisien, dan mampu berdaya saing dalam era globalisasi dan perdagangan bebas (Rachmadi Usman, 2001:84). Secara umum terdapat 3 (tiga) bentuk penyatuan usaha dalam hal ini usaha bank, yaitu merger, konsolidasi, dan akuisisi yang oleh UUPT diterjemahkan dengan "penggabungan, peleburan, dan pengambilalihan". Penyatuan usaha bank adalah dimaksudkan untuk mengatasi kesulitan yang membahayakan kelangsungan usaha bank yang bersangkutan atau perluasan usaha bank yang bersangkutan, sehingga bank menjadi kuat (Pasal 37 ayat 1 huruf d Undang-Undang Perbankan).

Tipe merger dalam kacamata ekonomi dan yang biasanya dipergunakan dan diaplikasikan dalam dunia usaha adalah tipe horizontal (horizontal merger), merger vertikal (vertical merger), dan merger konglomerat (conglomerate merger), sedangkan dalam kacamata hukum, tipe merger dilihat sematamata dari perikatannya, yaitu 
"statutory merger" yang diatur oleh syarat-syarat yang ditetapkan pemerintah dimana para pihak terikat suatu akta merger (istilah anglo saxon : act of merger) merupakan dokumen yang diajukan kepada pemerintah bersama-sama dengan dokumen merger terkait

(Cornelius

Simajuntak, 2004:26).

Kata "merger" berasal dari bahasa Inggris "merger", yang artinya "menggabungkan". Merger dapat diartikan sebagai penyatuan atau penggabungan dua perseroan atau lebih dengan cara mendirikan perseroan baru dan membubarkan perseroan lainnya. Jadi, satu perseroan atau lebih dapat menggabungkan diri menjadi satu dengan perseroan yang telah ada, dan salah satu perseroan yang ada tetap dipertahankan keberadaannya. Sehingga segala segala hak dan kewajiban yang ada dialihkan kepada perseroan penerima penggabungan. Sedangkan kata "consolidation" yang berarti peleburan diartikan penggabungan dua atau lebih perseroan dengan cara membentuk perseroan baru dan membubarkan perseroan yang bergabung tadi. Jadi beberapa perseroan yang ada bergabung atau menyatukan diri menjadi perseroan baru, dimana hak dan kewajiban perseroan diambil alih oleh perseroan yang telah dibentuk (Cornelius Simajuntak, 2004:86).

Peraturan perundangundangan yang berlaku di Indonesia memberikan pengertian (definisi) merger dengan rumusan kalimat yang hampir seragam, hanya pada UUPT. memberikan definisi khusus tentang "penggabungan" yang lebih lengkap, yaitu perbuatan hukum yang dilakukan oleh satu perseroan atau lebih untuk menggabungkan diri dengan perseroan lain yang telah ada yang mengakibatkan aktiva dan pasiva dari perseroan yang menggabungkan diri beralih karena hukum kepada perseroan yang menerima penggabungan dan selanjutnya status badan hukum perseroan yang menggabungkan diri berakhir karena hukum.

Pasal 1 angka 25 UndangUndang Perbankan, memberikan pengertian mengenai merger sebagai:

"Penggabungan dari dua bank atau lebih dengan cara tetap mempertahankan berdirinya salah satu bank dan 
membubarkan $\begin{aligned} & \text { bank-bank } \\ & \text { lainnya dengan atau tanpa } \\ & \text { melikuidasi". }\end{aligned}$

Definisi diatas kemudian

dimuat secara khusus dalam Peraturan

Pemerintah Nomor 28 Tahun 1999

Tanggal 7 Mei 1999 Tentang Merger,

Konsolidasi dan Akuisisi bank.

Sedangkan dalam hukum Pasar

Modal, istilah yang digunakan adalah istilah penggabungan usaha, dimana pengaturan mengenai perusahaan public diatur dalam Keputusan Bapepem No. Kep-52/ PM/ 1997 tentang Peraturan No. IX. G. I:

"Penggabungan Usaha adalah perbuatan hukum yang dilakukan oleh satu perseroan atau lebih untuk menggabungkan diri dengan perseroan lain yang telah ada dan selanjutnya perseroan yang menggabungkan diri menjadi bubar".

Alexander H. Frey, memberikan batasan (definisi) merger sebagai (Cornelius Simajuntak, 2004:5):

"a merger of corporation is the absorpotion by one corporation of one or more usually smaller corporations, which lose their identity bay becoming part of the large enterprise", (penggabungan adalah fusi atau absorpsi atau kombinasi antara 2 (dua) atau lebih perusahaan dimana 1 (satu) diantaranya merupakan perusahaan yang lebih kecil akan kehilangan identitasnya dan bergabung atau menjadi bagian dari perusahaan lain yang lebih besar).

Defenisi merger yang lain (Black's Law Dictionary: 682):

"The fusion or absorption of one thing or right into another, generally spoken of a case where one of the subjects is of less dignity or importance than the another", (Penggabungan atau penyerapan suatu hal kedalam hal lain, dimana salah satu subjeknya memiliki kepentingan yang lebih rendah dibandingkan yang lainnya)".

Merger didefinisikan oleh Pringle dan Harris (Pringle, J. J, and Harris, R. S, 1987:778) sebagai berikut: "Merger is a combination of two or more firm in which one company survives under its own name while any others cease to exit as legal entities". Jadi pada dasarnya merger adalah suatu keputusan untuk mengkombinasikan/menggabungkan dua atau lebih perusahaan menjadi satu perusahaan baru. Dalam konteks bisnis, merger adalah suatu transaksi yang menggabungkan beberapa unit ekonomi menjadi satu unit ekonomi yang baru. Proses merger umumnya memakan waktu yang cukup lama, 
karena masing-masing pihak perlu melakukan negosiasi, baik terhadap aspek-aspek permodalan maupun aspek manajemen, sumber daya manusia serta aspek hukum dari perusahaan yang baru tersebut. Oleh karena itu, penggabungan usaha tersebut dilakukan secara drastis yang dikenal dengan akuisisi atau pengambil alihan suatu perusahaan oleh perusahaan lain.

Menurut Cristian Wibisono, penggabungan perusahaan adalah penggabungan dua badan usaha atau lebih yang relatif berimbang kekuatannya sehingga terjadi kombinasi baru yang merupakan wadah bersama yang saling memperkuat (Cristian Wibisono, 1995:2).

Berdasarkan pengertian diatas, definisi merger begitu bervariasi dengan narasi kalimat yang panjang ataupun singkat, namun secara substansi kesemuanya mengandung pengertian yang sama, yaitu kombinasi (bergabungnya) 2 (dua) perusahaan atau lebih dimana perusahaan yang mengakuisisi akan mempertahankan identitasnya dan perusahaan lain akan bubar. Dengan demikian, pengertian antara merger dan konsolidasi bank jelas berbeda walaupun bentuknya adalah samasama penyatuan usaha, tetapi dalam merger hanya memerlukan perubahan anggaran dasar yang memerlukan persetujuan Menteri Kehakiman dan HAM sedangkan pada peleburan memerlukan akta pendirian hasil konsolidasi yang disahkan oleh Menteri Kehakiman dan HAM.

Penempatan terminologi ketiga penyatuan usaha tersebut (merger, konsolidasi, akuisisi) dalam tataran masyarakat sering menimbulkan kerancuan. Dalam bidang perbankan Indonesia pada tahun 1999 empat bank milik negara yaitu Bank Dagang Negara, Bank Ekspor Impor Indonesia, Bank Bumi Daya, dan Bank Pembangunan Indonesia melakukan menggabungkan diri (merger) menjadi PT. Bank Mandiri. Kemudian yang terakhir pada tahun tahun 2004, terjadi penggabungan usaha bank antara Bank CIC Internasional, Bank Danpac, dan Bank Pikko menjadi Bank Century. Meskipun secara teknis bukanlah penggabungan tetapi peleburan (konsolidasi) karena membentuk 
nama badan hukum baru, kecuali Bank Danamom yang melakukan merger dengan 8 (delapan) Bank take Over. Padahal ada perbedaan yang cukup signifikan diantara keduanya.

Garry D. Smith (Cornelius Simajuntak, 2004:2) mengatakan bahwa merger sering merupakan hasil dari beberapa perusahaan yang menyetujui untuk mengkombinasikan (bergabung) dan menciptakan suatu nama dan identitas baru, mengeluarkan saham baru, mengimplementasikan suatu struktur organisasi yang baru, dan membuat beberapa perubahan lainnya. Padahal secara teoritis, pengertian antara merger dan konsolidasi bank jelas sangat berbeda walaupun bentuknya adalah sama-sama penyatuan usaha, tetapi dalam merger hanya memerlukan perubahan anggaran dasar yang memerlukan persetujuan Menteri Kehakiman dan HAM sedangkan pada peleburan memerlukan akta pendirian hasil konsolidasi yang disahkan oleh Menteri Kehakiman dan HAM.

Konsepsi hukum merger
penting bagi perpajakan dan
perlakuan akuntansi, tetapi dari sudut

hukum perusahaan tidaklah vital, karena yang terpenting apakah tindakan merger (termasuk dalam konsolidasi) atau akuisisi termasuk kategori tindakan hukum perseroan yang sifatnya substansial yang dapat mempengaruhi kepentingan pemegang saham dan atau perseroan, dimana perlu persetujuan pemegang saham perseroan (Chattamarasjid Ais, 2004:93).

Berdasrkan uraian diatas, maka dapat disimpulkan bahwa pengertian merger berkembang melalui pertauran perundang-undangan, sedangkan pengertian akuisisi tumbuh dalam praktek secara harfiah diterjemaahkan sebagai "pengambilalihan" dan dalam konteks hukum perusahaan dapat berupa pengambialihan saham atau kekayaan. Dalam praktek tidak mudah untuk membedakan antara tindakan merger dengan akuisisi. Tidak jarang suatu transaksi yang secara formal bukan sebagai merger, melainkan secara materiil mempunyai akibat sebagai merger.

$$
\text { Selanjutnya }
$$
peraturan perundang-undangan juga mengatur akibat hukum dari merger tersebut. 
Pasal 122 UUPT menjelaskan berakhirnya perseroan karena dilakukan merger tanpa dilakukan suatu likuidasi terlebih dahulu, akibat hukumnya adalah:

a. Aktiva dan passive bank yang digabungkan atau meleburkan diri beralih krena hukum pada perseroan yang menerima penggabungan.

b. Pemegang saham perseroan yang menggabungkan diri menjadi pemegang saham perseroan yang menerima penggabungan.

c. Perseroan yang menggabungkan diri atau meleburkan diri berakhir karena hukum terhitung sejak tanggal penggabungan diri berakhir karena hukum terhitung sejak tanggal penggabungan mulai berlaku.

Sedangkan Pasal 2 PP No. 28

Tahun 1999 Tentang Merger, Konsolidasi, dan akuisisi Bank, menyebutkan bahwa merger mengakibatka :

a. Pemegang saham yang melakukan merger atau konsolidasi menjadi pemegang saham bank hasil merger

b. Aktiva dan passive bank yang melakukan merger atau konsolidasi, beralih karena hukum kepada bank hasil merger.

Berdasarkan kedua pasal di atas dapat dismpulkan bahwa, jika bank yang dibubarkan setelah merger, maka pembubaran tersebut hanyalah dilakukan secara administratif belaka, tanpa diikuti tindakan likuidasi.Jadi tidak ada pemberesan dan tidak ada membagi-bagi aset.

\section{Perancangan}

Model

Pengaturan Merger dalam

Kerangka Pembangunan

\section{Hukum Ekonomi Nasional}

Bank merupakan suatu lembaga yang berperan sebagai perantara keuangan (financial intermediary) antara pihak-pihak yang memiliki dana (surplus unit) dengan pihakpihak yang memerlukan dana (deficitunit) serta sebagai lembaga yang berfungsi memperlancar aliran lalu lintas pembayaran. Di samping itu, bank juga sebagai suatu industri yang dalam kegiatan usahanya mengandalkan kepercayaan masyarakat sehingga mestinya tingkat kesehatan bank perlu dipelihara. Kestabilan lembaga perbankan sangat dibutuhkan dalam perekonomian suatu negara. Kestabilan ini tidak saja dilihat dari jumlah uang yang beredar, namun juga dilihat dari jumlah bank yang ada sebagai perangkat 
penyelenggaraan keuangan

(http://eprints.uny.ac.id/8585/2/BA

B\%201\%20-06408141050.pdf).

Merger dalam bidang usaha perbankan BUMN, dimana sampai dengan tahun2008, terdapat 5 (lima) Bank Persero (Bank BUMN) yaitu Bank Mandiri, Bank Negara Indonesia, Bank Rakyat Indonesia, Bank Tabungan Negara dan Bank Ekspor Indonesia. Namun pada tahun 2009, Bank Ekspor Indonesia berubah bentuk badan hukumnya menjadi Lembaga Pembiayaan Ekspor Indonesia berdasarkanUU Nomor 2 Tahun 2009, sehingga perakhir Desember 2011 terdapat 4 bank BUMN yang seluruhnya telah listed.

Ada pun kinerja Bank BUMN tahun 2005-2010 pada umumnya meningkat yang antara lain disebabkan Bank BUMN telah berhasil dalam melakukan restrukturisasi, baik yang bersifat operasional maupun restrukturisasi finansial

(http://eprints.uny.ac.id/8585/2/BA B\%201\% 20-06408141050.pdf).

Kemajuan yang terjadi terhadap perbankan-perbankan
BUMN di Indonesia adalah salah satunya karena faktor-faktor merger terhadap Bank BUMN di Indonesia. Selain dari bank BUMN, tentu ada beberapa bank swasta yang melakukan merger, seperti Bank Permata. PT. Bank Permata Tbk (Bank Permata) merupakan hasil merger 5 (lima) Bank yaitu PT. Bank Bali Tbk, PT. Bank Universal Tbk, PT. Bank Artamedia, PT. Bank Patriot dan PT. Bank Prima Ekspress pada tahun 2002 dan saat ini telah berkembang menjadi sebuah bank swasta utama yang menawarkan produk dan jasa inovatif serta komprehensif terutama disisi delivery channel-nya termasuk Internet Banking dan Mobile Banking. Permata Bank memiliki aspirasi untuk menjadi penyedia jasa keuangan terkemuka di Indonesia, dengan fokus di segmen Konsumer dan Komersial. Melayani sekitar 2 juta nasabah di 60 kota di Indonesia, per Juli 2014 Permata Bank memiliki 329 cabang (16 Cabang Syariah \& 313 Cabang Konvensional), 20 Cabang Bergerak (Mobile Branch), tiga Payment Point, 940 ATM dengan akses dilebih dari 69. 000 ATM (Visa Plus, Visa 
Electron, Master Card, Alto, ATM Bersama dan ATM Prima) dan jutaan ATM di seluruh dunia yang terhubung dengan jaringan Visa, Mastercard dan Cirrus (www.bankpermata.com).

Merger dan akuisisi perusahaan perbankan dianggap sukses melihat berhasilnya merger dari bank papan atas seperti Bank Mandiri, Bank Danamon dan Bank Permata telah menarik minat bankbank pada papan menengah seperti Bank Haga dan Bank Hagakita untuk bergabung dengan pihak bank asing Rabobank. Dan terakhir ini kita melihat adanya minat dari bank-bank kecil menengah (Bank Harta, Bank Mitraniaga, Bank Harmoni) untuk melakukan strategi serupa. Strategi merger merupakan salah satu bentuk strategi populer, yang awalnya naik daun pada era tahun 1970an. Proses ini didorong oleh 3 faktor utama:

a. Semakin menyatunya sistem perekonomian regional dan perekonomian dunia.

b. Adanya ekspansi perusahaanperusahaan mnc ke berbagai negara, dan c. Berbagai terobosan teknologi informasi dan telekomunikasi setelah tahun 1980 yang memudahkan proses alih informasi dan kapital.

Pada kasus industri perbankan, krisis perekonomian yang terjadi di wilayah ekonomi Asia Timur dan Asia Tenggara pada tahun 1997 telah membawa dampak terjadinya kemelut di industri perbankan di dalam negeri. Cukup banyak lembaga perbankan yang menghadapi permasalahan dan bahkan kemudian kolaps akibat krisis tersebut.

Upaya penyelamatan dari bankbank yang masih bertahan kemudian tertolong dengan dijalankannya kebijakan "restrukturisasi finansial" dan strategi "merger dan akuisisi". Proses merger dan akuisisi di industri perbankan memang memiliki baik dampak yang positip maupun dampak yang negatip, tergantung dari perspektif kita memandangnya. Keberhasilan upaya merger dan akuisisi memerlukan keuletan dan jalan yang cukup berliku bagi berbagai pihak yang ingin sukses menerapkan kebijakan ini 
(http://repository.binus.ac.id/20092/content/J0104/J010464325.doc).

Krisis moneter di Indonesia mulai terjadi sekitar pertengahan Juli 1997, krisis moneter ini telah merubah aktivitas ekonomi negara. Mulai dari tahun 1997 sampai tahun 2001 banyak bank yang diberhentikan operasinya dan masuk dalam pengawasan BPPN (Badan Penyehatan Perbankan Nasional). Berkembangnya krisis menjadi semakin parah karena ditemukan adanya kelemahan mendasar pada sistem perekonomian Indonesia yang tercermin dari kurang efisiennya pengelolaan perekonomian dan sektor usaha serta rentannya sektor keuangan dan perbankan Indonesia. Krisis moneter ini telah berubah menjadi krisis ekonomi, yakni terpuruknya kegiatan ekonomi karena semakin banyaknya perusahaan yang tutup, perbankan yang dilikuidasi dan meningkatnya jumlah tenaga kerja yang menganggur, yang menunjukkan betapa besar dampak ekonomi yang akan ditimbulkan apabila terjadi kegagalan usaha perbankan. Dalam industri perbankan rasio kegagalan yang terjadi biasanya disebabkan oleh kegagalan dalam menangani portofolio kredit maupun kesalahan manajemen perusahaan yang berakibat pada kesulitan keuangan bahkan kegagalan usaha perbankan, sehingga pada akhirnya dapat merugikan kegiatan perekonomian nasional dan masyarakat selaku pemilik dana. Melemahnya sistem perbankan akan menimbulkan disfungsi sistem perbankan sebagai perantara.

Merger perbankan di Indonesia tentu akan memberikan dampak yang positif terutama terhadap perekonomian nasional, karena merger perbankan akan memberikan kepercayaan masyarakat terhadap perbankan untuk deposito, giro dan tabungan. Bagibank-bankbesardi beberapanegaramaju, seperti Amerika Serikat misalnya, selain aspek makro ekonomi dan mikro ekonomi yang dipertimbangkan dalam suatu keputusan merger, pihak pemerintah sering sekali memperhatikan aspekaspek yang bersifat struktural, yang meliputi tiga aspek. Pertama, aspek kesehatan dan keamanan. Artinya perusahaan baru hasil merger tersebut harus menjadi perusahaan yang sehat 
dan aman. Apabila perusahaan lama ada yang tidak sehat, maka harus bias diupayakan agar penyakit lama tersebut tidak boleh menular ke perusahaan hasil merger; Kedua, aspek kompetisi dan konsentrasi. Penggabungan perusahaan tidak boleh berakibat pada semakin terkonsentrasinya bisnis dalam industri karena tidak bias mendorong efisiensi di dalam bisnis tersebut; dan Ketiga, aspek pelayanan kepada masyarakat. Penggabungan usaha tidak harus mengurangi kualitas pelayanan bank kepada masyarakat luas (Agunan P. Samosir, 2003). Oleh karena itu, dalam merger perlu rancangan yang baik, paling tidak model Rancangan Merger Perbankan seperti dibawah:

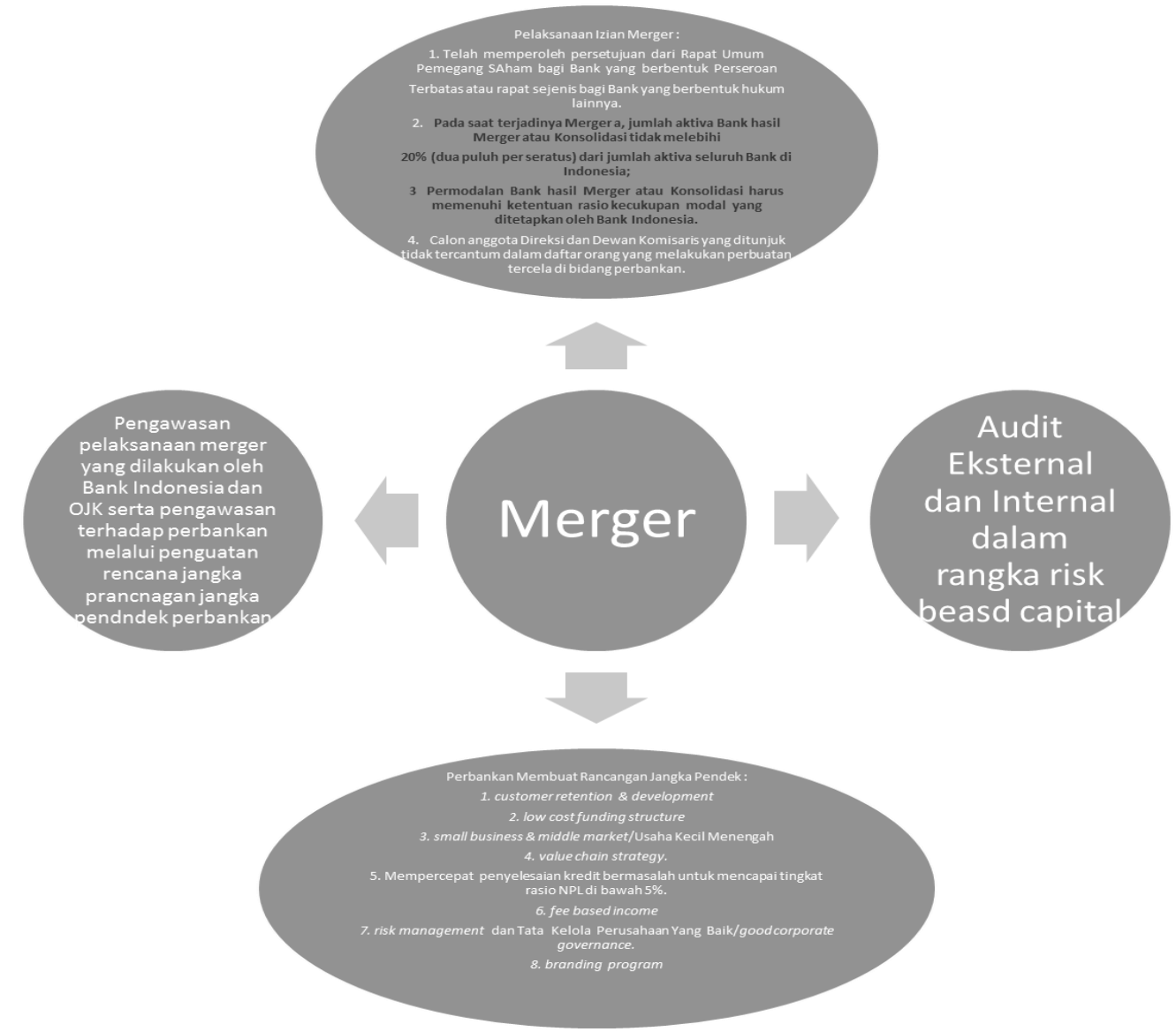

\section{SIMPULAN}

Selain aspek makro ekonomi dan mikro ekonomi yang dipertimbangkan dalam suatu keputusan merger,pihak pemerintah sering sekali 
memperhatikan aspek-aspek yang bersifat struktural, yang meliputi tiga aspek. Pertama, aspek kesehatan dan keamanan. Artinya perusahaan baru hasil merger tersebut harus menjadi perusahaan yang sehat dan aman. Apabila perusahaan lama ada yang tidak sehat, maka harus bisa diupayakan agar penyakit lama tersebut tidak boleh menular ke perusahaan hasil merger; Kedua, aspek kompetisi dan konsentrasi. Penggabungan perusahaan tidak boleh berakibat pada semakin terkonsentrasinya bisnis dalam industri karena tidak bisa mendorong efisiensi didalam bisnis tersebut; dan Ketiga, aspek pelayanan kepada masyarakat. Penggabungan usaha tidak harus mengurangi kualitas pelayanan bank kepada masyarakat luas.

\section{DAFTAR PUSTAKA}

Black's Law Dictionary, Seventh Edition.

Chattamarasjid Ais, Penerobosan Cadar Perseroandan Soal-Soal Aktual Hukum Perseroan, PT.
Citra Aditya Bakti, Bandung, 2004.

Cornelius Simajuntak, Hukum Merger Perseroan Terbatas, PT. Citra AdityaBakti, Bandung, 2004.

I Nyoman Tjager, et. al, Corporate Governance, Tantangan dan Kesempatan Bagi Komun itas Bisnis Indonesia, PT. Prenhallindo, Jakarta, 2003.

Pringle, J. J. , and Harris, R. S, Esentials of Managerial Finance, second edition, Illinois-London, 1987.

Rachmadi Usman, ,Aspek-Aspek Hukum Perbankan Di Indonesia, PT. Gramedia Pustaka Utama, Jakarta, 2001.

Agunan P. Samosir, Analisis Kinerja Bank Mandiri Setelah Merger Dan Sebagai Bank Rekapitalisasi,Jurnal Kajian Ekonomi Islam Vol. 7 No. 1 Maret 2003

Agus Sugiarto, Perlunya API, Harian Kompas, 5 Juni 2003.

Cristian Wibisono, Merger dan Akuisisi di Indonesia, Seminar Merger dan Akuisisi, Jakarta, 1995
http://eprints. uny. ac. $\mathrm{id} / 8585 / 2 / \mathrm{BAB} \% 201 \% 20$ - 06408141050. pdf.

http://repository. binus. ac. id/20092/content/J0104/J010464325. $\underline{\text { doc }}$ 
Agus Prihartono PS, Pengaturan Penggabungan Usaha (Merger) Bank...

www.Bank Permata.com 